\title{
Gender parity: Legal foundations and theological issues in the Democratic Republic of the Congo
}

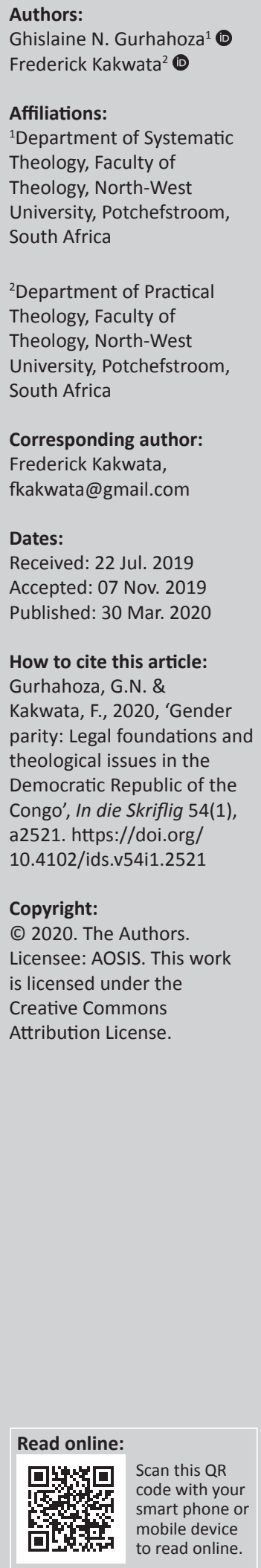

This study examines the legal foundations and the theological issue of gender equality in the Democratic Republic of the Congo (DRC), and proposes the adoption of an ethical approach towards the amelioration of this pertinent issue of human concern. Arguably, the achievement of gender equality in the DRC remains a myth, an objective to be realised, and a world of opportunity to be utilised. The argument pursued here is that the persistence of gender inequality has far-reaching consequences for all spheres of society. Therefore, it is crucial for women and men to be more proactive and work together towards the attainment of gender equality. This begins with the acquisition of adequate training for women in various fields. Thus, armed with the requisite knowledge and courage, women will be able to fully participate and effectively contribute to the advancement of society and the church in the same way as their male counterparts.

Keywords: gender parity; gender equality; complementarity; feminism; legal foundations; theological issues; Democratic Republic of the Congo.

\section{Introduction}

Historically, the status of women in most African societies has been characterised by issues such as patriarchal domination, gender stereotyping, suppression and violation of women, genderbased violence, race and class issues, and the victimisation of women and children in situations of socio-political conflict and religious extremism, to mention a few. These issues continue to inhibit the self-actualisation of African women today. Even in ecclesiastical circles, in comparison to their male counterparts, women theologians are subjugated and underappreciated.

Etymologically, the term parity originates from the lower Latin word paritas, which translates as 'parity', 'equality', or classical Latin pars: 'equal to, the same, matched, the same, the same strength, the same talent' (Dictionnaire politique 2006; Sita 2010:395; White 2016:1421). Parity is defined as equality or similarity between objects of the same quality or of the same nature. Synonymous with equality, balance, similarity and concordance, it also refers to equal representation between two groups and, in this case, equal distribution between men and women. The introduction of the term into the law, aims to correct the inadequacy of the balance sheet of women's eligibility, because parity is perfect equality compliance (Dictionnaire politique 2006). In politics, it refers to the equal representation of men and women in elected assemblies (cf. Petit la Rousse illustré 2016:841; White 2016:1421).

According to these definitions, parity refers variously to the availability of equal opportunity between men and women in different fields. Furthermore, it refers to the following: equal representation between two groups, equal payment for equal work and equivalent rank; equal political representativeness (right to vote, right to stand for election, composition of an elected assembly or government); access to equal leadership positions in companies or institutions (such as management positions, board of directors); equal access to employment (accessibility to a profession, equal opportunities in recruitment); and equal access to education (literacy, level of study) (Dictionnaire politique 2006). More specifically, parity in the work sphere entails equal payment for work of equal value (Thibaut 1980:160). In addition, parity encompasses the equitable representation of women, including the equal participation of men and women in the exercise of political responsibilities (Mbata 2012:111).

Parity posits the idea of equal access to opportunities and positions of responsibility in authority without discrimination. It advocates equivalent access to similar positions, and therefore equal pay for people with the same level of training, the same capacity without discrimination of any kind, or on any basis whatsoever. 
The core argument here is that, despite the existence of legal instruments aimed at the elimination of all forms of discrimination $^{1}$ against women, a wide chasm exists between the law in theory and the law in praxis, as gender inequality persists in both socio-professional and ecclesiastical circles. Based on this prevalent anomaly, it is logical to argue that a misinterpretation of the idea of gender equality exists. Therefore, it is pertinent to redefine the concept of gender equality in line with the law and theology, and the law and spirituality.

This study is a literature review: it seeks to unpack the concept of gender parity, gender based on laws of the Democratic Republic of the Congo (DRC), and a theological perspective of the dignity of the human being created in the image of God. To achieve this objective, the article uses a feminist ${ }^{2}$ theological approach to achieve a more inclusive analysis. The aim therefore is to explore the applicability of these laws to the enrichment of the spiritual substance of the churches in the DRC through the execution of effective gender-sensitive mission.

\section{Background on gender equality in the Democratic Republic of the Congo}

From a legal point of view, the argument on equality or parity is based on the provisions of Article 14 of the Constitution of the DRC, Article 4 of the Labour Code, which defines the notion of worker in its first paragraph and Article $29^{3}$ of the African Charter on Human and Peoples' Rights. The Constitution stipulates: '... when there are ten men, there must be ten women'. It also implies that gender parity should ideally be a reality rather than a subject of ongoing debate.

Unfortunately, despite the advancements in gender relations, the significant spread of feminist consciousness in sociocultural, political and ecclesiastical spheres, gender issues such as the patriarchal exclusion and limitation of women's theological autonomy persist. In the DRC, the status of women has equally not improved. The reason for this is that despite some efforts to develop gender-sensitive policies and programmes that would create better opportunities for women, and advance their inclusion in all aspects of life, gender parity is yet to be achieved. The law on parity and equal opportunities, enshrined in Article 14 of the Constitution of 18 February 2006, stipulates that public authorities must:

- ensure the elimination of all forms of discrimination against women by protecting and promoting their rights;

- takeall appropriate measures to ensure the full development and participation of women in the development of the nation, particularly in the civil, political, economic, social and cultural spheres; and to put an end to any discrimination that results in violence against women in public and private life.

1.Discrimination, whether intentional or unconscious, undermines not only equal rights and equal opportunities, but also the equal duties of all.

2.Feminist approach or feminist theology is not only a liberation theology, but also an inclusive theology - a theology in which all human beings are valued and play their part in creation (Beydon 1997:234; Parmentier 2009:53).

3.Emphasises the obligation of every citizen to work according to his or her abilities for the development of his or her community.
The same Constitution specifies that women have the right to equitable representation in national and local institutions, which the State must guarantee through public laws and standards binding on all citizens. Thus, the implementation of gender equality is enshrined as one of these requirements.

However, the crux of the matter is that there is a lackadaisical attitude towards the implementation of policies and enforcement of existing laws. More importantly, the concept of parity or gender equality is widely misunderstood; people who espouse the idea are often regarded with suspicion and subjected to rejection and denigration. The antagonism towards parity and gender equality discourse in Africa, comes from both men and women who view feminism with anxiety. Among the womenfolk, the idea of gender equality is also grossly misunderstood. This is partially because they do not grasp the scope and ideals of the concept, but also because of the ingrained socio-cultural internalisation of patriarchal ideals, which they have come to accept as the norm (Anderson 2010:114-115; Fulkerson 2018:101; Sproul 2006:133). Sadly this opposition against gender equality has dire consequences for women in Africa, particularly in the DRC where women continue to suffer exclusion, repression and subjugation in both domestic and public spheres and thus losing their dignity in societies with laws that should protect them, but fails to do so.

Presently it is impossible to assess the exact extent of gender inequality in the Congolese society, and to ascertain whether there has been any reduction in that regard, ${ }^{4}$ notwithstanding the fact that the 2006 Constitution of the DRC contains a 'revolutionary' provision regarding women's equal political participation. According to official statistics, Rwanda has made remarkable progress with a representation of $42 \%$ of its women in decision-making bodies, compared to the 30\% rate provided for in the Rwandan Constitution (Dictionnaire politique 2006).

On the contrary, the DRC has not made significant progress towards the achievement of parity. During the 2011 elections, women were underrepresented as electoral candidates and selected officials. There was no female candidate running for the Presidency of the Republic and the less than $10 \%$ female candidates represented, were up for deputation posts. In South Kivu, out of the total of 828 political candidates, only 59 were female candidates, making up for a meagre $7 \%$. In fact, most political parties refused to place women on their electoral lists. A similar scenario played out during the 2006 elections, with less than $10 \%$ female representation in parliament. The responsibility for this failure lies partly with the political parties, but also with civil societies, particularly women's rights organisations, which failed to consult, plan strategy and mobilise the political parties for a better representation of women candidates on their lists (Mawanzo 2008:4).

In the DRC, limited spaces are accorded to women in the national executive power. For instance, the percentage of women in the first national government to emerge from the 4.The DRC is excluded from the 2010 World Economic Forum (WEF) ranking, which measures gender inequality in 134 countries (Mawanzo 2008:4) 
2006 elections was incredibly low at 10.9\%. In February 2010, the cabinet shuffle led to the reduction of the number of ministries from 54 to 43 , and a subsequent decrease of the number of women ministers from six to five. In fact, a minute number of women exercise legislative power $(8.6 \%$ of Deputies, and $5.5 \%$ of Senators). For the various positions of authority and responsibility such as Mayor District Commissioner, Mayor District Territorial Administrator, the score varies between 6\% (Bas-Congo and Ecuador) and 25\% (South Kivu) (Mawanzo 2008:4).

Parity remains an ideal not only in the government of the DRC, but also in other areas such as state enterprises and the judiciary of civil and military courts where the representation of women remains outrageously low across the provinces. For example, South Kivu has 2 female Magistrates out of 54 or 3.7\%; Bandundu: 0 female out of 57; Ecuador: 0 female out of 78; Kasaï-Oriental: 3 females out of 88 , or $3.4 \%$; KasaïOccidental: 2 females out of 56, or 3.57\%; Bas-Congo: 5 females out of 214, or 2.34\%; Katanga: 18 females out of 243, or $7.41 \%$; Maniema: 1 woman out of 26 , or $3.85 \%$; North Kivu: 2 women out of 52 , or $3.85 \%$; in Orientale province: 2 women out of 61, or 3.28\% (Mawanzo 2008:4). Regarding state-owned enterprises such as the Office Congolais de Contrôle (OCC), the situation is no different from the other institutions. Out of the 153 officers at the headquarters of the Provincial Directorate of North Kivu (Goma), only 39 are women, including 30 junior managers. ${ }^{5}$

The gender disparity in the DRC has been attributed to women's lack of the requisite educational qualifications. This led to the analysis of the educational problem in the city of Goma, using the Universite Libre de Pays de Grands Lacs (ULPGL) as a case study. The aim was to compare the school attendance level of girls and boys at Kauta Nursery and Primary School, ${ }^{6}$ then at the secondary level at the Metanoia Institute $^{7}$ and finally, their evolution at university level (all faculties combined) over a period of 5 years. The observations showed that, initially at nursery school, the average number of pupils were 1567 , including 789 girls $(50.35 \%$, ) and 778 boys $(49.65 \%$.). At the primary school level, out of 4 207, there were 2161 girls (51.37), and 2046 boys $(48.63 \%)$. At this point, the representation of girls and boys were almost equal. However, the number of girls began to dwindle at the secondary school level. Thus, out of 4752 students, there were 2247 girls (47.29\%) and 2505 boys $(52.71 \%)$. At university, the average number of students recorded was 10635 including 3622 girls (34.06\%) and 7013 boys $(65.94 \%)$. Based on these findings, one could safely conclude that the lack of university and executive training excludes women from attaining positions of authority. Therefore, the availability of access to tertiary education should be the paramount priority for girls. As Mbata Mangu (2012:113) aptly argues: to achieve parity and promote women's participation in politics, investing in their education

5.Coordination Division, Monthly Activity Report March 2012 of the OCC.

6.The primary school of ULPGL.

7.The secondary school of ULPGL. and capacity building, would ensure that women are as competent as their male counterparts.

In addition, the issue of gender inequality is often discussed in four areas: economy, education, health, political representation, but the existence of this problem in the religious sphere seems to be overlooked.

After having examined the background on gender equality in the DRC, the following section will focus on the legal, social and ethical basis for parity.

\section{The legal, social and ethical basis for parity}

The concept of parity or gender equality is grounded in solid principles and can be analysed from a multiplicity of perspectives.

\section{Analysed from a legal perspective}

Several international legal instruments and agreements recognise parity as a right reserved for every human, and States are mandated to address underrepresentation by adopting measures to rectify the gender imbalance, and the elimination of all forms of discrimination against women (Convention on the Elimination of All Forms of Discrimination Against Women [CEDAW]). Article 23 (1), (2) and (3) of the Universal Declaration of Human Rights (UDHR) of 10 December 1948 provides that:

Everyone has the right to work, to free choice of employment, to just and favourable conditions of work and to protection against unemployment. Everyone has the right, without any discrimination, to equal pay. Everyone who works has the right to just and favourable remuneration ensuring for himself and his family an existence worthy of human dignity and complete, if necessary, by all other means of social protection.

In the same manner, Article 7 of the International Covenant on Economic, Social and Cultural Rights (1976:4) requires all Member States to improve working conditions so that remuneration provides a minimum subsistence level for all workers without distinction. Women particularly must be guaranteed that the working conditions granted to them are not inferior to those enjoyed by men, and that they receive the same remuneration for the same work. Furthermore the United Nations (United Nations Covenant II 1976:art. 6), in the International Covenant on Civil and Political Rights, condemns discrimination on the grounds of race, colour, sex, language, religion, political and other opinion, national or social origin, property, birth, or other status: 'All persons are equal before the law and are entitled, without discrimination, to equal protection of the law.'

At the regional level, the African Charter on Human and Peoples' Rights (June 1981), Article 15, stipulates equal payment for equal work. The provision of the right to work, requires states to develop programmes that promote the involvement of all citizens in the national development process. 
At the national level, Article 47, paragraph 1 of the Congolese Charter of Human and People's Rights (2001:18) states, 'every Congolese has the right and duty to work'. It is the duty of the State to ensure conditions of peace, security, justice and access to employment for all. In consonance with international anti-discrimination conventions, the Congolese law has aptly established the issue of equal representation of men and women in decision-making as a constitutional principle. Article 14, paragraph 4 of the Constitution, for example provides that 'women are entitled to equitable representation in national, provincial and local institutions'. As Mabiala (2011:167) argues, presently the bases for equality are founded on solid principles that are indisputable.

Thus, in the DRC, the notion of parity is contained not only in the Constitution, which is the fundamental law, but also in international laws which stipulate that everyone has the right to work, the right to employment, to fair and satisfactory conditions of work. Most importantly, local, regional and international laws stipulate that everyone deserves equal pay for work of equal value, without discrimination.

\section{From a social standpoint}

The notion of parity is propounded through diverse theories that espouse equality such as positive discrimination, which grants additional rights to socially disadvantaged groups in order to better equalise their opportunities. According to these theories, the substance of which John Rawls has condensed a just society, is characterised by equal civil rights and freedom for all. Therefore, as Rawls (1971:49-59) rightly avers, one cannot justify obtaining a greater good from some by usurping the freedom of others.

\section{From an ethical point of view}

Parity constitutes a moral requirement that arises from the very existence of differences, and the fight against the injustices in society (Thibaut 1980:40). The achievement of the Millennium Development Goals (MDG) constitutes one of the foundations of parity. ${ }^{8}$ The third goal (MDG3) explicitly aims at promoting gender equality, and the empowerment of women and action in favour of gender equality would help to relaunch the efforts needed to achieve it. To uphold human rights and dignity, and to promote holistic development, the contribution of everyone is necessary (Dictionnaire politique 2006).

This necessitates the examination of the concept of parity from a biblical perspective to enrich the conception of parity in society and even in the church.

\section{Biblical viewpoints on parity}

It is important to note that the term parity is a legal concept and does not exist in the Bible. Considering the definitions given above, the word equality will be used simultaneously in place of parity as a more suitable option of the exegesis that follows. Since the evolution of the church, the subject of the 8.The Millennium Development Goals, which were to go until 2015. role of women in the church has been controversial. Derouet et al. (1980:67) argue that the role of women was not primarily the subject of scriptural teaching as such, but the testimony of the Bible should be taken with the message it expresses, the situations it evokes, and the experiences it attests. These authors assert that, even though the Bible specifically seeks to bear witness to God's love for humanity through certain verses, it enunciates the contribution of women who distinguished themselves by their ways, and they acted together with men. The experiences of some of these women will be utilised later in this article to discuss the notion of equality in the Scriptures (Clowney 2000:243).

\section{Gender equality in the Old Testament}

In the beginning, men and women were created together in 'the image of God' (Gn 1:26-27) and were placed equally in the community of life. Together they were mandated to rule the world (Gn 1:28; Kuen 2002:226; Ruether 1991:262; Sita 2010:401). The image of God determines the vocation of the human being, a call to serve all as representatives of God, having the power and authority to govern. For the image of God ensures not only professional equality and mutuality open to all, but also equality that places men and women on an equal footing, whatever the task at hand (Ruether 1998:83, 84; Stephenson 2015:147). The image of God in the human being would also be an instigator of dignity and respect for all humans without distinction of sex (Grudem 2010:499; Robinson 2011:1).

According to Derouet et al. (1980), in the Old Testament (OT), the burdens of exercising the Yahweh religion was not exclusive to men. Women and men alike could offer sacrifices and participate in worship, but in the customs of the contemporary pagan people, also in the second temple, the worship was reserved for the men of the tribe of Levi (Derouet et al. 1980:71; Reijnen 2010:65). However, in the OT it was exceptional for women to play significant roles such as in leadership, or even to have a voice. Women like Myriam, Deborah, Huldah, Noahdiah and several others, played significant roles as prophets, while others like Esther were instrumental to the salvation of God's people at a critical time in their history.

Deborah represents an outstanding exemplary of remarkable women in the OT. The judge (Shôptîm) in Israel was responsible for not only the enforcement of justice, but also for the governance of the entire people. As judge, Deborah performed her duties under the 'Palm of Deborah', between Ramah and Bethel in Ephraim (Jdg 4:5). The people went to her receive counsel and she ensured peace among the people of Israel. Of the 12 judges who succeeded each other in Israel, only Deborah was a prophetess. In this capacity, she spoke on behalf of God and as Adeyemo (2008:303) puts it, it was as Commander-in-Chief that she summoned her Chief of Staff, General Baraq. God had already determined the number of troops that Baraq had to bring, which tribes they had to come from, where the army had to position itself and what the result would be, as he promised victory to Baraq. 
Deborah simply relays the divine order to Baraq from the Lord, the God of Israel: 'go and recruit on Mount Tabor and take with you ten thousand men of the sons of Naphtali and Zebulun' (Jdg 4:6). In verse 8, Baraq insists that he will only embark on the mission if Deborah goes with him. What this implies is that he needed her to accompany him and assist him by her great influence to conquer (Auzou 1965:201). Despite God's promise of victory in Judges 4:7, Baraq remains hesitant. Nonetheless Deborah acknowledges the word of the Lord as the centre of their common mission and equips Baraq with the confidence and courage he requires to act. In addition, she offers him direction as a partner, based on the guidance she receives from God. Just like the queen bee, ${ }^{9}$ she manages to gather the tribes for the war against the attacks of Yabin, the Canaanite king of Hatsor, whose troops were commanded by Sisera. Ultimately, Deborah's revolutionary actions convinced Baraq, and he agrees to accompany the valiant warrior (Manyanya 2011:60).

Deborah's story is an apt demonstration of true equality and complementarity in action. That is a situation whereby everyone, irrespective of their gender and differences, performs their responsibility while receiving from the other due respect and dignity. Deborah and Baraq were called to defend the cause of the people. Despite his military prowess, Baraq acknowledges Deborah's intelligence and spiritual wit, and cooperates with her and agrees to be under her direction. As a woman equipped with spectacular wisdom, she works as the leader of the group and guides Baraq and his men to achieve resounding victory for Israel. The power of complementarity and the productivity that can be achieved from the collaboration between men and women, are depicted in this passage. Deborah is happy to assist Baraq and she plays her part efficiently. Therefore, even though the divine directive is relayed through her, it is to her that the victory that God gives to Israel, is attributed (Jdg 5:13). It is by working together that Baraq successfully attacks and descends with his troops from Mount Tabor (Jdg 4:14).

As Adeyemo (2008:303) rightly points out, God's gifts are transmitted by the Holy Spirit to anyone he chooses (Ac 1:14; 2:1-4, 17-18) regardless of gender. For him, the presence of other prophetesses in the Bible such as Miriam (Ex 15:20), Houlda (2 Ki 22:14), Noadiah (Neh 6:14), Ann (Lk 2:36) and Philip's four daughters (Ac 21:9), together with Deborah, are clearly evince that leadership in the church and society is a gift from God, which is freely given irrespective of gender. In agreement with Adeyemo, the story of Deborah proves that with God's support and in a combination of charisma, courage and competence, women can be effective leaders.

The repressive traditions that inhibited women's empowerment notwithstanding, Deborah's resilience proved remarkable. Working closely with Baraq, and without consideration to gender, but each according to their task, abilities and responsibilities, they jointly defended the cause of the children of Israel. Deborah's collaboration with Baraq 9.The name Deborah means Bee (Manyanya 2011:60). reinforces the fact that God's plan is for men and women to find mutual solutions for the problems of humanity, by being in peaceful communion with one another. This narrative highlights this egalitarian (parity) aspect between man and woman, which is realised in complementarity.

\section{The representation of gender equality in the Gospels}

In the New Testament (NT), especially in the Gospels, the teachings and conduct of Jesus Christ elucidates the notion of equality. In stark contrast to his socio-cultural environment, specifically the contemporary Jewish laws and customs, Christ's attitude reflects impressive novelty. This is because his teachings and social advocacy were neither discriminatory based on gender, nor race, nor class. Unlike 1st century Judaism and rabbinical teachings that disregarded the humanity of women (Adeyemo 2008:303; cf. Ngongo 2009:9, 20; Oduyoye 2001:61, 64; Phiri 1997:74; 2005:90, 92), Jesus Christ respected the women who followed and served him (Lk 8:2-3). Mary of Bethany is described as an exemplary disciple for 'listening attentively to the teaching' (Lk 10:39-42). Women were responsible for announcing the resurrection to the Apostles and Peter (Mk 16:7). Although Jesus Christ did not explicitly teach about women, his attitude and behaviour towards women and the role they played in his ministry, were significant and revolutionary.

Derouet et al. (1980) identify the Sermon on Mount Sinai in Matthew's Gospel as the starting point of the Law and the New Assembly. They argue that Christ would have constituted the new assembly through the promulgation of the Law and the miracles he performed without gender distinction (Derouet et al. 1980:69). Matthew asserts that all traditional barriers are dismantled, and women have been admitted into the new assembly. Zumstein (1991:67-68) opines that John's Gospel prioritises the status of women in the NT by depicting women who are both examples of faith comparable to the beloved disciple and apostolic witnesses of the kerygma. L'Eplattenier (1993:93) also asserts that John emphasises the role of women as witnesses, especially Mary Magdalene who, according to tradition, was 'the apostle of the apostles'. Rekha Chennattu, the Samaritan woman represents the epitome of a mature Christian and a committed apostle (Chennattu 2007:385). The narrative of the Samaritan woman in the fourth chapter of the Gospel of John, highlights the notion of equality portrayed in the Gospels. The Samaritan woman concerns a woman who displays exceptional courage despite the harsh conditions faced by Jewish women at that time. Given the limited rights and duties accorded to women in the Jewish society, she was not supposed to participate in public life. However, she contravened the law. According to the Gospel of John (4:27-30), when the disciples arrived, they were outraged to see their master talking to a woman - a being of lesser social status, an abominable act for men in the East (Kuen 2004:39; Van den Bussche 1967:197). The woman hastily withdrew from the well, leaving her jug behind; she went to share the good news with her compatriots (Jn 4:28). As Chennattu (2007:392) observes, it was vital for the Samaritan woman to 
share her new faith, and her words 'a man told me everything I did', aroused people's interest. Consequently, they went out in considerable numbers to meet Jesus Christ (Jn 4:30). By sharing her testimony of faith, the woman became a witness of Christ to her relatives.

Contradictorily, Van den Bussche (1967:195) discredits the Samaritan woman's testimony, and maintains that she is far from preaching faith to the Messiah, because she had only asked herself the question: 'Isn't it the Messiah?' For him, she is neither a missionary, nor a true believer. However, John Walvoord and Roy Zuik (1983) suggest that her question was tinged with a sense of a probability if one considers the fact that it was unlikely for a woman, especially a woman with her reputation, to make such a dogmatic statement. Just as Jesus captured her attention by awakening her curiosity, it arouses his curiosity and that of his compatriots so much that they are forced to reflect on the issue (Walvoord \& Zuik 1983:230). However, several recent studies such as those of Chennattu, (2007:382) and Djomhoué (2010:133), contend that the Samaritan woman is an innate charismatic evangelist who does not need to know much to profess the good news. Therefore, rather than remain docile, she would simply proclaim what she learned from her conversation with Jesus Christ. John 4:39-42 narrate the woman's testimony and the subsequent depiction of genuine faith by many Samaritans who, through her testimony, had a personal encounter with Jesus Christ (v. 41). In John 4:42, the Samaritans told the woman that they no longer believed just because of her word, but also based on their own individual conviction that Jesus is truly the Saviour of the world (Maertens 1967:132).

Jesus Christ who is the saviour of the world, personally dismantled the repressive traditions that relegate women, and set the precedent for gender equality. Maertens (1967:132) recalls that, under the laws of circumcision, only the men were regarded as full members of the chosen people, because they underwent the ritual; woman, on the other hand, were secondary citizens and were accepted through their alliance with their fathers or husbands. Under the baptismal regime, this right is equally accessible to all, whether uncircumcised or not, or whether male or female. Currently baptism qualifies both men and women as missionaries and incorporates them likewise into the household of God (D'Aquin 2008:150).

Evidently, Jesus Christ recognises not only women's right and access to theological knowledge, but also their right to become missionaries alongside their male counterparts. Just like Jonah brought conversion to the city of Nineveh, the Samaritan woman went through Samaria bearing witness to Christ and converted numerous people. In line with Schüssler Fiorenza's (1994:454-455) argument that missionary conversion is analogous to the call to discipleship, as Andrew called his brother Peter to be a disciple of Jesus Christ by telling him, 'we have found the Messiah', so does the woman's testimony encourage the Samaritans to come to Jesus. Likewise, as Nathanael became a disciple because Jesus Christ knew what he had done under the fig tree, so too, the Samaritan woman becomes a disciple because of her words, 'He told me everything I ever did.'
The narrative of the Samaritan woman proves that every disciple of Jesus Christ has the mission of proclaiming the gospel of salvation to the world. This means that, within the body of Christ, both men and women are mandated to proclaim the message of reconciliation. Therefore, like this woman who utilised her modest knowledge of the word of God to bring followers to Christ, all Christians should testify according to their abilities and knowledge.

In conclusion Jesus Christ inaugurated a new order in Hebrews 8 that fundamentally annulled - 'made obsolete' (Heb 8:13) - all pre-existing strictures and espouses equal dignity in the social and spiritual relations between men and women. The new covenant, promulgated by Christ, emboldens both men and women to work according to their individual capacities and abilities as granted by the Holy Spirit.

\section{Gender equality in the epistles}

The epistles attest that women played significant roles in the early days of Christianity. Phoebe was a deaconess (Madigan \& Osiek 2011:5-6; Rm 16:1), and Junias and Priscilla participated in the leadership of the Early Church (Jay 2014:122; Mathew 2013:96; Ntamushigo 2017:36, 39-45; Paquette 2008:248-249). This suggests that, in the Early Church, there was a certain equality between men and women. As Daniel Marguerat (2008:263) points out, gender equality in religious settings was a rare phenomenon in Greco-Roman society and Christianity would constitute the only religious offer of truly egalitarian communities. Fabris (1987:47) is of the opinion that, on the basis of first-hand historical information, it is possible to define more precisely the ecclesial presence and role of women in the missionary community founded by Paul or related to his evangelisation project.

The letter of the apostle Paul to the Galatians (3:26-29) clearly expresses the notion of equality. It states that all believers are sons of God through their faith in Christ Jesus. This passage explicates what equality in Christ entails: familial adoption as children of God through faith (v. 26); clothed with Christ through baptism (v. 27); neither distinctions nor discriminations exist in Christ (v. 28); and joint heritage of the promises made to Abraham (v. 29). What this implies is that all who believe, are baptised in Christ and their live in Christ are no longer under the restrictions and divisions of the law. As Patterson (2018:24) states, this credo emphasises that distinction based on race, class and gender are not on real foundations. According to Kuen, it would be the only text on the status of women in doctrinal development and not among the corrective directives, which proffers an absolute repealing of all differences between the three pairs, namely Jewish and Greek peers, slaves and free men, and men and women (Kuen 2004:67). Christ therefore instituted profound changes in human relationships by creating a classless society, and a new relationship based on love.

The social implications of Galatians 3:28 for Jews and Greeks cannot be neutralised in the church by limiting them to man's relationship with God (salvation). Paul did everything in his 
power to apply the principle of equality to the reality of his churches (Kuen 2004:67). Once clothed with Christ, Christians live in a state of equality, or better, still unity (Gl 3:28) (Grudem 2002:20-21), stripped of all prerogatives and particularism. All believers are clothed in the dignity of Christ who died for them, and in whom they were baptised. For Stephen Patterson $(2018: 24,25)$ this implies that all are included by virtue of their faith in Christ. This gender equality particularly does not only concern salvation, but also ethical norms as Kuen (2004:67) points out. In agreement with Sesboüé (2016:579), one could say that Galatians 3:26-29 should be the watchword and rallying flag for all those who fight for gender equality in all spheres of human activity, that is, 'The Great Charter of Humanity'.

Based on the foregoing considerations, one can argue that the objective theological status acquired in Christ, affects both the functional and social dimensions of the existence of nonJews in the body of Christ. Within the church, they enjoy the same liberty and perform the functions as Jews. This leads to the conclusion that the woman, having been denigrated to the same condition as non-Jews, automatically benefits from the liberties granted the other two pairs. The irony, however, is that, presently, more than 2000 years later, the church continues to perpetuate the obsolete culture of depriving women of the rights granted to them by Christ. This 'statutory equality' should ideally afford women functional equality in the church. Franz-J. Leenhardt (1978:33) declares that the harmonious coexistence of men and women should be upheld in the church more than elsewhere. This is because Jesus Christ teaches everyone his place in creation and his own vocation. He is the one who inspires them and helps them to fulfil themselves in love.

Contrary to what was obtainable in Judaism, the Christian community should be comprised of equal partners. What this means, is that women have as much access to a full religious identity as men, because the rite of aggregation in the Christian community no longer hinges on circumcision, but on baptism in Christ (D'Aquin 2008:150; Zumstein 1991:69). Marguerat (2008:263) believes that the diversity of the nascent church should be attributed to Pauline theology, which would be the result of his missionary strategy. He claims that the apostle founded inclusive communities based on his understanding that God embraces individuals regardless of their identities, social role, status or loyalties and his comprehension of the death of Christ. Therefore, Paul perceives the event of the cross as the end of Israel's particularism; a conviction that he aptly summarises as follows: 'There is neither Jew nor Greek, male nor female, slave nor free, for you are all one in Christ Jesus' (G1 3:28).

\section{Conclusion}

The existence of international, regional and domestic legal instruments and agreements, provides the basis for the elimination of all forms of discrimination against women. In the DRC, however, despite the existence of the law ensuring equality between men and women, gender inequality persists in both socio-professional and ecclesiastical circles. Parity is yet to be achieved. This propels the suggestion that Congolese women must strive towards the achievement of parity as nothing is given, but the fight for equality can never be realised without the proactive collaboration of men. The quest for parity does not involve confrontations. Instead, it necessitates the acknowledgement of women's capabilities and their ability to execute them efficiently. As Sita MuilaAkele (2010:405) rightly indicates, it is a challenging issue to tackle; nonetheless, it is achievable. It is pertinent to reevaluate our stance as a society, reassess our values, and revolutionise education with the overall objective of rebuilding a state based on not only the rule of law, but also one that prioritises human rights and gender parity.

As foregoing discussions show, the adoption of gender equality or parity at all levels of society would surely promote the development of humanity. Therefore, it is crucial to implement equal access to adequate training facilities in different fields of human endeavour, as this is an inextricable prerequisite for women empowerment. From a theological point of view the OT declaration of all human beings being created in the image of God, becomes the foundation of gender equality. In the NT, the message, the action of Christ, and being in Christ would be a precedent for gender equality. Jesus inaugurated a new order rooted in equal dignity whereby men and women participate in missionary work, as exemplified by the Samaritan woman. In the same manner, men and women should have equal access to positions of authority and responsibility within the church, based on their abilities (gifts of the Holy Spirit) and skills (adequate biblical formation), as the story of Deborah epitomises.

In summation, the argument herein has been that women can be as effective as any male leader, provided they have the support of God and a combination of charisma and character, courage and competence. Therefore, if men and women were propelled by their love for God in all their undertakings, gender parity would be easily attainable. The onus rests on the church in the DRC to reassess the full participation of women in ministry functions, and to eschew all cultural constraints that inhibit the full liberty and participation of women. The author concurs with Schüssler Fiorenza (1994:454) that, if the exclusion of Christian women from breaking bread and deciding on their own spiritual wellbeing and commitment persists, then Ekklesia, as a community of equal disciples, will never be realised. This would, in turn, have negative consequences for the posterity of the power of the gospel.

It is vital to note at this point that what is posited here is not a battle of the sexes, but the existence of gender balance in a situation in which each individual recognises his or her abilities and work in solidarity with each other towards the accomplishment of the betterment of everyone. Hence, it is crucial to recognise that this cannot be accomplished by one gender without the full participation of the other. By eschewing all forms of competition or rivalry and working as 
equals, men and women complement each other. It is only by doing so that gender parity can be achieved - not only in the DRC, but also all over the world!

\section{Acknowledgements \\ Competing interest}

The authors declared that no competing interest exists.

\section{Authors' contributions}

Both authors contributed equally to this work.

\section{Ethical consideration}

This article followed all ethical standards for a research without direct contact with human or animal subjects.

\section{Funding information}

This research received no specific grant from any funding agency in the public, commercial, or not-for-profit sectors.

\section{Data availability statement}

Data sharing is not applicable to this article as no new data were created or analysed in this study.

\section{Disclaimer}

The views and opinions expressed in this article are those of the authors and not necessarily reflect the official policy or position of any affiliated agency of the authors.

\section{References}

Adeyemo, T., 2008, Commentaire biblique contemporain, Farel, Paris.

African Charter on Human and People' Rights, 1981, Adopted by the Eighteenth Assembly of Chiefs of State and Government, Nairobi, viewed 21 April 2018, from www.achpr.org/fr/instrument/achpr.

Anderson, R.-S., 2010, On being human: Essays in theological anthropology, Wipf \& Stock, Eugene, OR.

Auzou, G., 1965, La force de l'esprit: étude du livre des juges, l'Orante, Paris.

Beydon, F., 1997, 'Qu'est-ce que la théologie féministe?', in G. Turckheur (ed.), En compagnie de beaucoup d'autres ... : Guide théologique du protestantisme contemporain, pp. 233-234, Berges et les mages, Paris.

Bitota, M.J., 2010, 'La parité homme-femme dans le domaine public, un principe constitutionnel', in A. Nzadi-a-Nzadi, M.G. Kambale, K.V. Tekila, B. Indiang \& N.T. Tshishimbi (eds.), Congo-Afrique, pp. 221-241, CEPAS, Kinshasa.

Convention on the elimination of all forms of discrimination against women (CEDAW), 1979, viewed 25 May 2019, from https://fr.wikipedia.org/wiki/ Privacy-Policy/fr; https:// www.ohchr.org/copyright.aspx/fr/About us/pages/ copyrigth.aspx.

Chennattu, R., 2007, Les femmes dans la mission de l'église: Interprétation de Jean 4 dans son entier [Women in the Church Mission: Interpretation of John 4 in his whole] pp. 381-396, Institut catholique de Toulouse, Toulouse.

Clowney, E., 2000, L'église: Collection théologique, Excelsis, Paris.

Congolese Charter of Human and People's Rights, 2001, Acts of the nationa conference on human rights, vol. 2, Centre Protestant d'édition et de Diffusion, Kinshasa.

Congolese Constitution, 2006, Constitution of the Democratic Republic of the Congo, 18 February 2006, 47 years, N0 special, Article 14, Official Journal of the Democratic Republic of the Congo, Office of the President of the Republic, Kinshasa.

D’Aquin, T., 2008, Commentaire d'épitre aux Galates, Cerf, Paris.

Derouet, H., Eroue, H., Kuen, A. \& Rogien, J., 1980, Femme dans la société et dans l'église, Cerf, Paris.

Dictionnaire de politique, 2006, Parité, viewed 21 April 2018, from https://www. toupie.org/Dictionnaire/Parite.htm.
Djomhoué, P., 2010, 'La samaritaine, une pionnière de la mission évangélisatrice dans le Nouveau Testament', in M-H Robert, J. Matthey \& C. Vialle (éds.), Figures bibliques de la mission, Exégèse et théologie de la mission: Approches catholiques bibliques de la mission, Exégese et theologie de la mission: Appr
et protestantes, Lectio Divina 224, pp. 119-133, Cerf, Paris.

Fabris, R., 1987, La femme dans l'église primitive, Nouvelle cité, Paris.

Fiorenza, S.E., 1994, In memory of her: A feminist theological reconstruction of Christian origins, Crossroad Publishing, New York.

Fulkerson, M.C., 2018, 'The imago Dei and a Reformed logic for a feminist/womanist critique', in M. Cortez \& M.P. Jensen (eds.), T \& T Clark reader in theological anthropology, pp. 100-106, Bloomsbury, London.

Grudem, W., 2002, 'The key issues in the manhood-womanhood controversy, and the way forward', in W. Grudem (ed.), Biblical foundations for manhood and womanhood, pp. 19-70, Crossway Books, Wheaton, IL.

Grudem, W., 2010, Théologie systématique: Introduction à la doctrine biblique, Excelsis. Paris.

International Covenant on Economic, Social and Cultural Rights, adopted by the United Nations General Assembly on 16 December 1966, 3/6/1976, viewed 07 March 2016, from http://echodesmontagnes.hautetfort.com/media/00/02/ 2902764694.pdf.

Jay, E.E., 2014, Junia, une femme apôtre ressuscitée par l'exégèse, Labor et fides, Genève.

Kuen, A., 2002, La femme dans l'Église [The woman in the church], éditions Emmaüs, Saint-Légier-La Chiésaz.

Kuen, A., 2004, La femme dans l'Église [The woman in the church], éditions Emmaüs, Saint-Légier-La Chiésaz.

Leenhardt, F.-J., 1978, La place de la femme dans l'Eglise d'après le Nouveau Testament [The place of women in the Church according to the New Will], Westminster, Philadelphia, PA.

L'Eplattenier, C., 1993, L'évangile de Jean [The Gospel of John], Labor et Fides, Genève.

Mabiala, N., 2011, 'Le leadership et gouvernance par les femmes professeurs d'universités en RD Congo' [Leadership and governance by women professors universities in DR Congo]', in A. Nzadi-a-Nzadi, M.G. Kambale, K.V. Tekila, B.G. Indiang \& N.T. Tshishimbi (eds.), Congo-Africa, vol. 453, pp. 195-206, CEPAS (Centre pour l'action sociale), Kinshasa.

Madigan, K. \& Osiek, C. (eds.), 2011, Ordained women in the early church: A documentary history, Johns Hopkins University Press, Baltimore, MD.

Maertens, T., 1967, La promotion de la femme dans la Bible [The advancement of women in the Bible], Casterman, Brussels, Belgium.

Manyanya, N.L., 2011, Figure des femmes dans l'Ancien Testament et traditions africaines [Figures of women in the Old Testament and traditions African], Harmattan, Paris.

Marguerat, D., 2008, L'aube du christianisme [The dawn of Christianity], Labor et Fides, Genève.

Mathew, S., 2013, Women in the greetings of Romans 16:1-16: A study of mutuality and women's ministry in the letter to Romans, Bloomsbury \& Clark, London.

Mawanzo, E., 2008, 'Parité', in E. Mawanzo, Observatoire de la parité, viewed 13 February 2018, from https://observatoiredelaparite.org/wp.

Mbata, M.A., 2012, Barack Obama et les défis du changement global, Harmattan, Paris.

Ngongo, K., 2009, Femme et paix dans la ville de Bukavu de 1996 à 2006: Réflexion théologique, Editions de l'Université protestante au Congo (EDUPC), Kinshasa.

Ntamushigo, G.G., 2017, 'The work of the Holy Spirit and the engagement of women in God's mission: A case study of revival churches in Lubumbashi', MA thesis, North-West University, Potchefstroom.

Oduyoye, M.A., 2001, Introductions in feminist theology: Introducing African women's theology, Sheffield Academic Press, Sheffield.

Paquette, S., 2008, Les femmes disciples dans l'évangile de Luc: Critique de la rédaction, Thèse présentée à l'université de Montréal, Montréal.

Parmentier, E., 2009, 'La théologie féministe victime de son succès? Les évolutions récentes: Un état des lieux', in Revue des sciences religieuses, vol. 83, pp. 1-14, viewed 06 September 2017, from https://rsr.revues.org/484

Patterson, S., 2018, The forgotten creed: Christianity's original struggle against bigotry, slavery, and sexism, University Press, Oxford.

Petit la Rousse illustré, 2016, Paritaire, La Rousse, Paris.

Phiri, I.A., 1997, 'Doing theology in community: The case of African women theologians in the 1990s', Journal of Theology for Southern Africa 99, 68-76.

Phiri, I.A., 2005, 'Peacemaking and reconciliation: The contribution of African indigenous religious women in KwaZulu-Natal, South Africa', Journal of Theology for Southern Africa 123, 84-92.

Rawls, J., 1971, Théorie de la justice, éd. du Seuil, Paris.

Reijnen, A.-M., 2010, 'Sexes, genres humains: Un itinéraire théologique', in J. Famerée, $\mathrm{M}-\mathrm{R}$ Hanneau, E. Parmentier \& A-M Reijnen, Le christianisme est- il misogyne? Place et rôle de la femme dans les églises, pp. 57-80, Luner Vitae, Bruxelles.

Robert Illustré \& Internet, 2006, Parité, La Rousse, Paris.

Robinson, D., 2011, Understanding the 'Imago Dei': The thought of Barth, Von Balthasar \& Moltman, Ashgate, London.

Ruether, R.R., 1991, 'Imago Dei, Christian tradition and feminist hermeneutics', in K.E. Borresen (ed.), Image of God and gender models Judeo-Christian tradition, pp. 258-281, Humanity Press, New York, NY.

Ruether, R.R., 1998, Introducing redemption in Christian feminist, Sheffield Academic Press, Sheffield. 
Sesboüé, B., 2016, 'Exégèse patristique de l'épitre aux galates', in I. Bochet \& M. Fédou, Recherche de science religieuse, vol. 103/104, pp. 579-582, Recherche de Fedou, Recherche de scienc
science religieuse, Paris.

Sita, M.A., 2010, 'La parité dans une RD Congo en mal des équilibres', in A. Nzadi-aNzadi, M.G. Kambale, K.V. Tekila, B.G. Indiang \& N.T. Tshishimbi (eds.), CongoAfrica, vol. 445, pp. 395-407, CEPAS, Kinshasa.

Sproul, R.C., 2006, Truths we confess: A layman's guide to the Westminster Confession of Faith, vol l: Triune God (chapters 1-8 of confession), P\&R Publishing, Phillipsburg, NJ.

Stephenson, L.P., 2015, 'Made in the image of God: A theological apologetic for women preachers', in L.R. Martin, Toward a Pentecostal Theology of Preaching pp. 141-153, CPT, Cleveland, $\mathrm{OH}$.

Thibaut, O., 1980, Débout les femmes, Chronique Social, Paris.
United Nations Covenant 2, 1976, International Covenant on Civil and Political Rights of 16 December 1966, viewed 13 February 2018, from www. humanrights/.../droits.

Universal Declaration of Human Rights, 1948, Nation Unies, viewed 21 April 2018 from www.un.Org/frUniversel-declaration.

Van den Bussche, H., 1967, Jean: Livre des signes, livre des œuvres, livre de adieux, livre de la passion, Desclée, Brouwer.

Walvoord, J.F. \& Zuik, R.B., 1983, Commentaire biblique du chercheur, Béthel, Québec.

White, E.F., 2016, 'Parité', in Le Robert (ed.), le Robert illustré \& son dictionnaire internet, pp. 1421, la Rousse, Paris.

Zumstein, J., 1991, Miettes exégétiques [Exegetical crumbs], Labor et Fide, Genève. 